IJIEF: International Journal of Islamic Economics and Finance

Vol. 1 (2), pg 145-164, January 2019

\title{
Analysis of E-Banking Acceptance in Oman: The Case of Islamic Banks' Customers
}

\author{
Abdelghani Echchabi \\ Higher Colleges of Technology, United Arab Emirates, Abdelghani.mo@gmail.com \\ Salim Al-Hajri \\ A'Sharqiyah University, Oman, drsalim_amor@asu.edu.om \\ Islam Nazier Tanas \\ Westcliff University, United States, islamnottingham@gmail.com
}

Article History

Received: November 13, 2018 Revised: January 1, 2019 Accepted: January 4, 2019

\begin{abstract}
The main objective of this study is to examine the factors that influence the customers' intention to adopt E-banking services in Oman across the Islamic Banking sector. This research endeavours to assess the willingness of the Islamic banks' customers to adopt these services rather than the traditional banking methods. Accordingly, a sample of 300 Islamic banks' customers were surveyed in different districts of Oman. Afterwards, linear regression and one sample $t$-test were utilized in order to analyse the gathered data. The findings showed that customers have high tendency of embracing and utilizing E-banking services as opposed to the conventional services. Additionally, the results revealed that relative advantage, self-efficacy, ease of use, and facilitating conditions are the fundamental factors that impact the selection of E-banking by Islamic banks' customers in Oman. However, uncertainty had no significant effect on the intention of Islamic banks' customers to use E-banking services. These findings would significantly contribute to the theory, and the way that Islamic banking sector would be practiced and regulated.
\end{abstract}

Keywords: Technology Acceptance, Theory of Planned Behaviour, Electronic Banking, Islamic Banking, Oman

JEL Classification : D81,G21, 032, O33, O35

@ IJIEF 2019 published by Universitas Muhammadiyah Yogyakarta, Indonesia All rights reserved

DOI:

https://doi.org/10.18196/ijief.128

Web:

http://journal.umy.ac.id/index.php/ijief/article/view/128

Citation:

Echchabi, A., Al-Hajri, \& S., Tanas, I. (2019). Analysis of E-Banking acceptance in Oman: The case of Islamic Banks' Customers. International Journal of Islamic Economics and Finance (IJIEF), 1(2), 145-164. DOI: https://doi.org/10.18196/ijief.128. 
Echchabi, Al-Hajri, \& Tanas | Analysis of E-Banking acceptance in Oman: The Case of Islamic Banks' Customers

\section{Introduction}

Contemporary Islamic finance has emerged in the past few decades not only as a complementary component in dual banking systems, but has also been positioned as a viable alternative to the long existing conventional banking system in many countries. However, the conventional banking system is still relatively dominant in many aspects. One of these aspects is the advanced and improved Electronic banking (E-banking) system that was conceived and set up long before the establishment of the modern Islamic banking system. It is evident in this regard that having a developed and secure E-banking system contributes in enhancing the performance and efficiency of banks, and attracting and retaining customers as well (Chong, Ooi, Lin and Tan, 2010; Jalal, Marzooq and Nabi, 2011; Alhinai, et al., 2013; Alkailani, 2016). Ebanking is also known as internet banking, online banking, web banking, and virtual banking. This form of banking allows the users to manage their bank accounts and perform various banking transactions via the Internet and using their smartphones without the need to visit a bank branch.

In Oman, Islamic banking was introduced in 2012 by the establishment of the first Islamic Bank, namely, Bank Nizwa after the release of the Islamic Banking Regulatory Framework (IBRF) by the Central Bank of Oman, officially allowing the introduction of full-fledged and Islamic banking windows in the country. This was subsequently followed by the introduction of other Islamic financial institutions including Meethaq Islamic Bank, Al-Yusr Islamic Bank, and Al-Izz Islamic bank.

Since its introduction in Oman, the Islamic banking industry has registered a robust and steady growth, estimated at an average annual growth of 14 per cent in financing by the end of $2017^{1}$. However, it still faces high and tremendous competition from the long-established conventional banks in many regards. It is noteworthy that in other settings (e.g. Malaysia), it was observed that one of the reasons why some Islamic banks were not patronised by customers is their lack of a handy, advanced and effective Ebanking system (Echchabi and Olaniyi, 2012).

As such, the purpose of this study is to explore and evaluate the adoption patterns of E-banking services by Islamic Banks' customers in Oman, and the factors that influence their decisions. This will certainly provide significant insights to the Islamic banks' managers for the improvement of the banking technologies and enhancement of the competitiveness with the conventional banks.

\footnotetext{
${ }^{1}$ https://timesofoman.com/article/122448 accessed on October 14th, 2018
} 
Echchabi, Al-Hajri, \& Tanas | Analysis of E-Banking acceptance in Oman: The Case of Islamic Banks' Customers

The rest of the paper is organised according to the following section: the second section will discuss the major studies in the E-banking acceptance by costumers in addition to the research model. The third section will detail the data which provide about the demographic information about the respondents. The forth section describes the methodology that was implemented in order to analyse the data. The fifth section is concerned about the results of the surveyed customers, while the sixth section is concerned about analysing the data. Section seven is going to present the conclusion, and will be followed by the recommendation which is showed in section eight.

\section{Literature Review}

\section{E-banking Acceptance}

The subject of E-banking and its acceptance among banks' customers has been heavily discussed in the previous literature both theoretically and empirically. For instance, Daneshgadeh and Yildirim (2014) investigated the factors impacting internet banking usage by Turkish bank customers. The study covered a sample of 500 respondents and used partial least square test for data analysis. The authors found that perceived usefulness, perceived ease of use and personalization have a strong impact on the customers' acceptance and usage of E-banking services.

In another context, Mukhtar (2015) attempted to evaluate the perception of E-banking services by the British bank customers. The study randomly selected a sample of 100 respondents. Using simple descriptive statistics, the authors found that privacy, security, convenience, and time saving were the main important dimensions to the customers.

Agha and Saeed (2015) examined the factors influencing customers' acceptance of online banking in Pakistan. A total of 200 respondents were randomly selected from Rawalpindi and Islamabad cities. Using regression analysis, the authors found that perceived credibility, perceived usefulness, and social risk have a significant effect on customers' adoption of online banking services.

Alkailani (2016) also investigated the perception and adoption of E-banking in Jordan. The study covered a sample of 500 respondents, and used exploratory factor analysis and linear regression for data analysis. The findings revealed that perceived ease of use, perceived usefulness, perceived trust, and perceived risk have significant effect on the adoption of E-banking services in Jordan.

IJIEF: International Journal of Islamic Economics and Finance, 1(2), 145-164| 147 
Echchabi, Al-Hajri, \& Tanas | Analysis of E-Banking acceptance in Oman: The Case of Islamic Banks' Customers

Khater, et al. (2016) explored the factors influencing customers' acceptance of internet banking services in Sudan. The study covered a sample of 207 respondents and applied SEM in the analysis. Their findings indicated that internet connection quality is the main factor that has direct effect on the behavioural intention to use internet banking in Sudan.

In a different context, Khan, et al. (2017) studied the factors leading to customers' intention to use E-banking services in Malaysia. The study covered a sample of 200 respondents. The findings showed that convenience, trust, perceived ease of use, and perceived usefulness have a significant positive impact on the customers' intention to adopt E-banking services in Malaysia.

In the specific case of Islamic banking, Feraro-Banta (2014) examined the perception of Islamic banks' customers in Bahrain about E-banking services. The study covered a sample of 200 bank customers and used mixed methodology approach, triangulating both quantitative and qualitative outputs. The findings showed that Islamic banks' customers in Bahrain are actively using E-banking services for their daily banking operations. Furthermore, the Islamic bank customers have shown high expectations regarding the E-banking services of Islamic banks, especially in terms of funds' transfer.

On the other hand, Zainuddin (2014) explored the determinants of E-banking adoption by Islamic banks' customers in Malaysia. The author found that perceived ease of use, perceived usefulness, security, trust and cost have a significant effect on the customers' adoption of E-banking services. Moreover, perceived usefulness was fund to have the highest influence on Islamic banks' adoption of E-banking services.

More recently, Echchabi (2018) investigated the level of acceptance of Ebanking services among Islamic banks' customers in various regions of Thailand, covering a total sample of 500 respondents. The author used descriptive statistics, one sample $t$-test, and structural equation modelling (SEM) for data analysis. The findings revealed that Islamic banks' customers in Thailand have a high tendency to use E-banking services across different groups. Moreover, the results showed that perceived ease of use has a significant positive impact on perceived usefulness. In addition, both perceived ease of use and perceived usefulness were found to have a significant positive impact on customers' adoption of E-banking services. 
Echchabi, Al-Hajri, \& Tanas | Analysis of E-Banking acceptance in Oman: The Case of Islamic Banks' Customers

\section{Theoretical Model}

Throughout the past decades, researchers explored some useful models in order to measure the user acceptance behaviour of Information technology and Information systems. The proposed models are Technology Acceptance Model (TAM), Theory of Reasoned Action (TRA), Theory of Planned Behaviour (TPB), or the Diffusion of Innovations Theory (DIT).

TAM has been developed by Davis (1989) is a standout amongst the most well-known research models to forecast to what extend users can embrace and utilize information systems and technology. TAM has been generally considered and confirmed by various researches that assessed the individual technology acceptance behaviour in various information systems concepts.

In TAM framework, there are two main factors that affect the user's intention of using innovative technology, perceived usefulness and perceived ease of use. According to Davis (1989, p.320), perceived usefulness refers to "the degree to which a person believes that using a particular system would enhance his or her task performance", while perceived ease of use refers to "the degree to which a person believes that using a particular system would be free of effort". These two factors are further affected by external dimensions, namely, social, cultural, and political factors (Ziefle and Jakobs, 2010).

Social factors incorporate language, skills and facilitating conditions. The used language in the information systems influences the individual's attitude towards the developed technology. If the underlying technical language used is easy to understand, then individual is likely to exhibit a positive attitude towards the technology. The opposite is correct when the language used is challenging and complex. In this case, a negative attitude towards using the technology will be observed (Ziefle and Jakobs, 2010). Another crucial factor regarding technology adoption concerns qualifications and skills of the potential users. In this regard, the more skilled and qualified are the users, the higher would be the positive attitude towards the technology, and vice versa. On the other hand, the facilitating conditions reflecting the extent to which the organization can provide technical support to the technology users, prepares a proper setting where the individual will be at ease in using the technology and consequently stimulates a positive attitude to adopt it (Ziefle and Jakobs, 2010).

On the other hand, the cultural factors are mainly obtained from Hofstede's cultural dimensions' theory (Hofstede, 1980), which are Individualism versus collectivism (IDV), uncertainty avoidance index (UAI), and power distance Index (PDI). The Individualism versus collectivism (IDV) refers to the degree 
Echchabi, Al-Hajri, \& Tanas | Analysis of E-Banking acceptance in Oman: The Case of Islamic Banks' Customers

to which one observes the connection between one's self and the group where he or she belongs (Hofstede, 1997). In the individualist culture, individuals are expected to stand up for themselves and prioritise their own interests over the group's. In contract, in the collectivist culture, the individual's interests and decision making are based on the group which they are loyal to.

Uncertainty avoidance (UAI) is a social dimension which measures to what extent the societies are tolerant of uncertainty. The high uncertainty avoidance societies develop rigid rules and standards which are step-wise strictly followed in order to limit obscure and uncertain conditions. On the other hand, low uncertainty avoidance societies have as few standards as possible, they endure changes and embrace the changing circumstances (Hofstede and Bond, 1984).

Power Distance Index (PDI) reflects to what extent individuals accept and expect equal distribution of power. High power distance societies are characterised by the autocratic relationships and inequalities between their members, while the low power distance societies are characterised by democratic relationships and equality between members (Hofstede and Bond, 1984).

Moreover, the political dimensions are mainly the effect of utilizing information systems in the political environment. This can be observed widely in social networks such as, Facebook, Twitter, and blogs and in social media such as, YouTube, e-newspapers, videos and mobiles (Teo, Lee, and Chai, 2008).

It is noteworthy that TAM was subsequently supported and applied by several empirical studies, and was also adapted by including other dimensions to suit different fields of study, including the E-banking area (Echchabi, 2011; Siraye, 2014; Rahi, et al., 2017; Fawzy and Esawai, 2017).

On the other hand, the TRA was first introduced to the social psychology field and has been mostly used to explain the relationship between attitude and behaviour. TRA suggests that behaviour is determined by an individual's intention to be involved in a specific behaviour (Ajzen and Fishbein, 1980).

According to TRA, there are two major factors that contribute in predicting behavioural intention, namely, attitude towards the behaviour and subjective norms. The first factor is concerned with the consequences that individual can obtain if he or she performs the behaviour (outcomes). The second factor is concerned with the individual's perception of what the referent groups would believe about his or her behaviour. 
Echchabi, Al-Hajri, \& Tanas | Analysis of E-Banking acceptance in Oman: The Case of Islamic Banks' Customers

Attitude towards the behaviour mirrors the person's belief about the desired outcome when the individual performs a specific behaviour and his or her own positive or negative evaluation of these outcomes. The theory proposed that the intention of specific behaviour would increase when the individual has a positive evaluation of the result gained from performing the behaviour (Ajzen, 1991).

Subjective norm alludes to a person's apparent social pressure to perform or not to perform a targeted behaviour. The subjective norm is a composite dimension of regulating convictions about a specific behaviour and the person's motivation to comply with relevant others (Fishbein and Ajzen, 1980). Normative beliefs show one's view of the impact of assessment among reference groups while motivation to comply demonstrates the degree to which the individual needs to follow the desires of the referent other (Mathieson, 1991). The hypothesis suggest that individuals frequently act based on their view of what others expect from them. Hence, their intention to adopt a behaviour is likely to be impacted by groups who they are belonging to.

Since its establishment, TRA was supported by many empirical studies (e.g. Sheppard, et al., 1988). However, subsequent researchers noticed lack of robustness and strength of TRA, since its two dimensions were deemed not sufficient to explain human behaviour (Warshaw and Davis, 1985; Davis, Bagozzi and Warshaw, 1989). Hence, an additional improvement of TRA was performed by some scholars, and extended later to TPB (Ajzen, 1991).

TPB is actually an expansion of TRA, which includes a construct that incorporates the challenge or easiness of performing a given behaviour, namely, Perceived behavioural control. The latter was added as a solid indicator of intention, which is deemed to have a larger effect compared to attitude and subjective norm. Ajzen justified this extension of the TRA for its weakness in managing behaviour over which individuals have inadequate volitional control (Ajzen, 1991). Particularly, perceived behavioural control is based on the study of TRA and Bandura's concept of "self-efficacy", which is associated with the idea of "how well one can execute courses of action required to deal with prospective situations" (Bandura, 1982, p. 122). He postulates that three variables, namely, attitude, subjective norms and perceived behavioural control can affect behaviour. The perceived behavioural control is reflected in terms of both self-efficacy and facilitating conditions. Accordingly, Ajzen (1991) recommends that behaviour is significantly affected by people's trust in their own capacity to perform the behaviour. As such, Ajzen proposed that on one hand, perceived behavioural control and behavioural intention will impact the actual behaviour, and on the other hand, perceived behavioural control, subjective norms, and 
Echchabi, Al-Hajri, \& Tanas | Analysis of E-Banking acceptance in Oman: The Case of Islamic Banks' Customers

attitude will influence behavioural intention. In light of the numerous researches related to TPB, Ajzen articulated that the new dimension furnished a noteworthy enhancement when contrasted to TRA.

Afterwards, several empirical studies have effectively connected TPB to the internet banking area in forecasting individuals' intention and behaviour toward Internet banking service such as, Harrison, et al. (1997), Liao, Shao, Wang and Chen (1999), and Klobas and Clyde (2000), Gopi and Ramayah (2007), Lee (2009), Nasri and Charfeddine (2012), Al-Ajman and Md Nor (2013), as well as Al-Shbiel and Ahmad (2016).

DIT was introduced by Rogers (1983) and could be considered as one of the oldest theories that investigate factors that influence a person's decision to embrace an innovation or advanced technology (Sahin, 2006). In this regard, Rogers defines the diffusion of an innovation as "the process by which an innovation is communicated through certain channels over time among the members of social systems". The main idea of DIT is that adopting new innovation is occurs within a set of sequential procedures in order to reduce uncertainty. Therefore, people need to put a substantial effort to collect information to form a believe about the new innovative technology. Consequently, this belief will play a major role in making decision whether to accept or reject the technology.

Rogers (1983) identified five major factors of adopting new technology. First is relative advantage, which is "how much the innovation is seen as being better than the idea it overrides" (Rogers 1983: 212). This requires the adopter to trade-off between the expected benefits and the cost of embracing the innovation, which can be articulated in economic or social form. The second factor is compatibility, which is defined as "how much the innovation is observed to be consistent with current values, pervious experiences, and the needs of potential adopters". The computability of innovation is being assessed with respect to the adopter's socio-cultural values and previous innovations, and customer wants for innovative technology. Regarding E-banking, innovation is reliable with the users' present approaches for monetary transactions and the innovation does not conflict with their present values. Thus, the innovation has a better opportunity to be adopted. The third factor is complexity, which describes the degree of difficulty of the innovation to be understood or used (Rogers, 1983: 242). Complexity shows the amount of physical or mental effort that can be exerted by the user to utilize the innovative technology. It is obvious that the idea of complexity is opposed to the ease of use concept that has been claimed by Davis (1989) in TAM. The forth factor is trialability, which defines the quality or the degree to which the innovation can be tested by the user prior to usage (Rogers, 1983: 243). Trialability provides the user 
Echchabi, Al-Hajri, \& Tanas | Analysis of E-Banking acceptance in Oman: The Case of Islamic Banks' Customers

great opportunity to explore the innovation before committing. This can be achieved for instance by releasing a demo or beta version of the digital services. Thus, potential adopters can experience the service and its possible effect on their daily activities after using it. The final factor is observability, which refers to the extent to the benefits of utilizing the innovation are visible to the user as well as his social environment. This is possible since the potential users usually observe the existing users of the innovation and clearly see the advantage of adopting and using the innovation (Rogers, 1983: 244). DIT received wide recognition and was heavily used in behavioural studies in various fields (Brown, Hope, Mugera, Newman and Stander, 2004; Carter and Campbell, 2011; Sanni, et al., 2013; Yuksel, 2015).

In light of the analysis of the above empirical studies and models, it was noticed that empirical studies found inconclusive and contradicting results related to different context, and with regards to specific dimensions and factors. In addition, it was noticed that these models were sometimes merged together to reach a better understanding and prediction of behavioural decision. As such, these notes have been considered, and the following model and corresponding hypotheses have been developed:

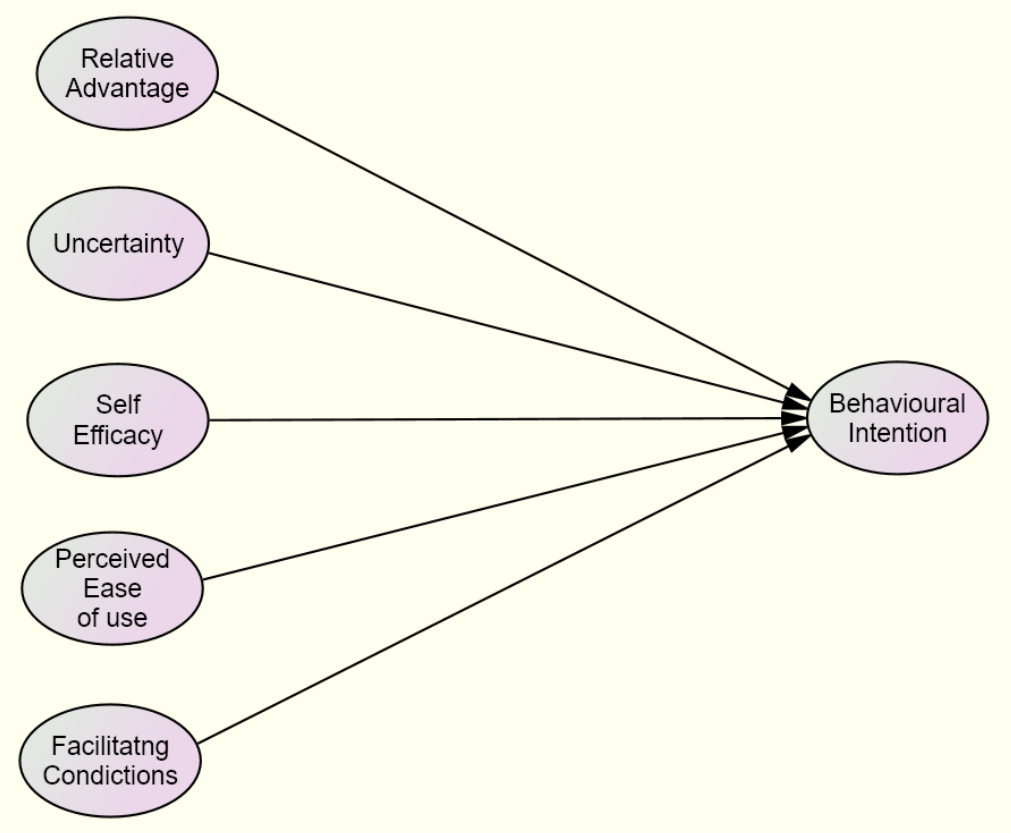

Figure 1. Research model 
Echchabi, Al-Hajri, \& Tanas | Analysis of E-Banking acceptance in Oman: The Case of Islamic Banks' Customers

H1: Relative advantage has a positive influence on the intention of Islamic banks' customers to use E-banking services in Oman

H2: Uncertainty has a negative influence on the intention of Islamic banks' customers to use E-banking services in Oman

H3: Self-efficacy has a positive influence on the intention of Islamic banks' customers to use E-banking services in Oman

H4: Perceived ease of use has a positive influence on the intention of Islamic banks' customers to use E-banking services in Oman

H5: Facilitating conditions have a positive influence on the intention of Islamic banks' customers to use E-banking services in Oman

H6: The Islamic banks' customers in Oman are willing to use E-banking services

\section{Methodology}

\section{Data}

Since the current study analyses the acceptance of E-banking services by Islamic banks' customers in Oman, the study population is mainly the Islamic banks' customers in various regions in Oman. Specifically, the estimated target sample size was 300 respondents in line with the previous similar studies in the field of innovations and technology adoption (e.g. Hill, 1998; Bartlett, et al., 2001; Nulty, 2008; Echchabi and Abdul Aziz, 2013). Out of the distributed questionnaires, only 188 responses were usable. Thus, a response rate of nearly 63 per cent was achieved.

For data collection purposes, a structured questionnaire was developed to gather perceptions of the Islamic banks' customers in Oman regarding the Ebanking services. Specifically, Likert type scaling was used to measure this information (where 1 = Strongly disagree and $5=$ Strongly agree). In this regard, 28 items were listed in this section, by adapting them from the existing E-banking literature as well as the general technology adoption models (e.g. Rogers, 1983; Ajzen, 1991; Davis, 1989; Echchabi, 2011; Echchabi and Abdul Aziz, 2013), as well as from the current finance and electronic banking literature with the necessary adaptations made for the specific context of the study. The second part of the questionnaire gathered the respondents' demographic information, i.e. gender, age, and education level. The questionnaire was prepared in English and was translated into Arabic and was subsequently distributed in both versions. 
Echchabi, Al-Hajri, \& Tanas | Analysis of E-Banking acceptance in Oman: The Case of Islamic Banks' Customers

Table 1. Respondents' Profile

\begin{tabular}{llc}
\hline \multicolumn{1}{c}{ Demographics } & \multicolumn{1}{c}{ Categories } & Percentage \\
\hline Gender & Male & 40.4 \\
\multirow{3}{*}{ Age } & Female & 59.6 \\
& Less than 20 years & 7.4 \\
& 20 to 30 years & 38.8 \\
& 31 to 40 years & 32.4 \\
& 41 to 50 years & 17 \\
Education level & More than 50 years & 4.4 \\
& High school level & 13.3 \\
& Undergraduate level & 65.4 \\
& Postgraduate level & 21.3 \\
\hline
\end{tabular}

The summary of the respondents' profile in Table 1 shows that 59.6 per cent of the respondents are female, while 40.4 per cent are male. Regarding the age grouping, 38.8 per cent of the respondents are aged between 20 and 30 years old, 32.4 per cent of the respondents are aged between 31 and 40 years old, and 17 per cent of the respondents are aged between 41 and 50 years old, 7.4 per cent of the respondents are less than 20 years old, and finally 4.4 per cent of the respondents are more than 50 years old. In terms of education level, 65.4 per cent of the respondents are undergraduate degree holders (Diploma and Bachelor's degrees), 21.3 per cent are holding a postgraduate degree, and 13.3 per cent of the respondents are high school certificate holders.

\section{Analysis Methods}

The collected data were analysed afterwards using linear regression analysis and one sample $t$-test through SPSS software version 23. It is noteworthy that in the regression model, the dependent variable is the intention to use E-banking in Oman in the specific case of Islamic banks, while the independent variables are relative advantage, uncertainty, self-efficacy, perceived ease of use, and facilitating conditions. Hence, the linear regression equation can be written as follows:

$$
I=\beta_{0}+\beta_{1} R A+\beta_{2} U+\beta_{3} S E+\beta_{4} P E U+\beta_{5} F C+\varepsilon
$$

Where

$\beta_{0}$ is a constant term

$\beta_{i}$ are regression coefficients

PEU refers to perceived ease of use

$U$ refers to uncertainty 
Echchabi, Al-Hajri, \& Tanas | Analysis of E-Banking acceptance in Oman: The Case of Islamic Banks' Customers

RA refers to relative advantage

FC refers to facilitating conditions

SE refers to self-efficacy

I refers to the customers' intention to adopt E-banking services

And $\varepsilon$ is an error term

On the other hand, the one sample $t$-test is used to compare the mean value of each construct item with the neutral point of the 5-points Likert scale i.e. the value of 3 . This test is mainly applied to the behavioural intention items to examine the willingness of the Islamic banks' customers to use E-banking services.

\section{Results and Analysis}

\section{Results}

The factors included in the current model were developed using a wellstructured questionnaire. Each factor was measured through at least three items. Table 2 presents the reliability of each factor, which is measured through Cronbach Alpha. In this regard, a Cronbach Alpha greater or equal to 0.6 is considered to be acceptable (Nunnally, 1978). The results indicate the Cronbach Alpha for the factors is between 0.721 and 0.859 . Hence, the measurement is reliable and valid.

In order to test the hypotheses posited above, linear regression is used for the first five hypotheses, while one sample $t$-test is used to test the sixth hypothesis. Table 3 summarises the linear regression that outlines the factors that influence the customers' intention to use E-banking services. The findings reveal that relative advantage has a significant positive effect on the intention of Islamic banks' customers to adopt E-banking services. Hence, hypothesis 1 is supported.

In contrast, the uncertainty associated with the E-banking transactions was found to have no significant effect on their adoption by Islamic banks' customers. Thus, hypothesis 2 is rejected. On the other hand, the results indicate that self-efficacy has a significant positive effect on the intention of Islamic banks' customers to use E-banking services. As such, hypothesis 3 is supported. 
Echchabi, Al-Hajri, \& Tanas | Analysis of E-Banking acceptance in Oman: The Case of Islamic Banks' Customers

Table 2. Reliability measures

\begin{tabular}{ll}
\hline Constructs & Cronbach Alpha \\
\hline Relative advantage & 0.787 \\
Uncertainty & 0.755 \\
Self-efficacy & 0.859 \\
Perceived ease of use & 0.721 \\
Facilitating conditions & 0.799 \\
Behavioural intention & 0.828 \\
\hline
\end{tabular}

Table 3. Linear Regression Output

\begin{tabular}{|c|c|c|c|c|c|}
\hline \multirow[b]{3}{*}{ Model } & \multicolumn{5}{|c|}{ Standardized } \\
\hline & \multicolumn{2}{|c|}{ Unstandardized Coefficients } & \multirow{2}{*}{$\begin{array}{c}\text { Coefficients } \\
\text { Beta }\end{array}$} & \multirow[b]{2}{*}{$\mathrm{t}$} & \multirow[b]{2}{*}{ Sig. } \\
\hline & $\mathrm{B}$ & Std. Error & & & \\
\hline (Constant) & 1.076 & .327 & & 3.290 & .001 \\
\hline Relative Advantage & .190 & .061 & .222 & 3.099 & .002 \\
\hline Uncertainty & -.037 & .064 & -.039 & -.574 & .567 \\
\hline Self-Efficacy & .128 & .064 & .138 & 2.017 & .045 \\
\hline Perceived Ease of Use & .211 & .070 & .215 & 3.025 & .003 \\
\hline Facilitating Conditions & .264 & .055 & .309 & 4.770 & .000 \\
\hline
\end{tabular}

In addition, the relative ease of use of the E-banking services was found to have a significant positive effect on their adoption by the Omani Islamic banks' customers. Hence, hypothesis 4 is supported. Similarly, the facilitating conditions have a significant positive effect on the adoption of E-banking services by Omani Islamic banks' customers. Thus, hypothesis 5 is supported.

In summary, out of the factors initially included in the model, four were found to have a significant impact on the Islamic banks' customers' intention to use E-banking services in Oman, namely, relative advantage, self-efficacy, perceived ease of use, and facilitating conditions. These factors explain 33.6 per cent of the Islamic banks' customers to use E-banking services.

Finally, to test the willingness of the Islamic banks' customers to use Ebanking services, one sample $t$-test was applied and its results are summarised in Table 4. In this regard, the results show high positive $t$-values for all the behavioural intention items, with significant probability values. This indicates that the Islamic banks' customers in Oman are willing to use Ebanking services. Thus, hypothesis 6 is supported. 
Echchabi, Al-Hajri, \& Tanas | Analysis of E-Banking acceptance in Oman: The Case of Islamic Banks' Customers

Table 4. One Sample t-Test

\begin{tabular}{lcrrr}
\hline & \multicolumn{1}{c}{$\mathrm{t}$} & df & Sig. (2-tailed) & Mean Difference \\
\hline $\mathrm{BI} 1$ & 11.944 & 187 & .000 & .77660 \\
$\mathrm{BI}$ & 12.641 & 187 & .000 & 1.00000 \\
$\mathrm{BI} 3$ & 11.776 & 187 & .000 & .82979 \\
$\mathrm{~B} 14$ & 15.209 & 187 & .000 & .90426 \\
$\mathrm{BI} 5$ & 12.052 & 187 & .000 & .70213 \\
$\mathrm{BI} 6$ & 11.984 & 187 & .000 & .74468 \\
\hline
\end{tabular}

\section{Analysis}

The above findings are in line with Rogers (1983), Agha and Saeed (2015), Alkailani (2016), Zainuddin (2014), and Echchabi (2018) with regards to the relative advantage of E-banking services compared to the traditional methods of banking and its significant positive effect on the customers' intention to use E-banking services. This advantage is primarily valued by customers in terms of the total cost of transactions, and time-saving advantage when using E-banking services, as well as the additional social prestige generally offered by these services.

The findings are also in line with Ajzen and Fishbein (1980) regarding selfefficacy that was found to have a significant positive effect on intention to use E-banking services. This indicates that generally, the Omani Islamic bank customers perceive themselves to have the required technical skills and knowledge that help them to use E-banking services, as they are currently offered.

On the other hand, regarding ease of use, the findings are in line with Davis (1989), Daneshgadeh and Yildirim (2014), Alkailani (2016), Khan, et al. (2017), Zainuddin (2014) and Echchabi (2018) who found that ease of use has a significant positive effect on the intention to use E-banking services. Particularly, ease of use for the E-banking services is mainly measured according to the extent to which it is easy for the customers to conduct the daily banking operations, the extent to which the banking procedures are easy and clear to be understood, as well as the extent to which E-banking services are easy to use for the continuous management and follow up of bank accounts. Hence, these dimensions significant in understanding behaviour towards E-banking and should be stressed by the decision makers and practitioners to further enhance the use of E-banking by Islamic banks' customers in Oman. 
Echchabi, Al-Hajri, \& Tanas | Analysis of E-Banking acceptance in Oman: The Case of Islamic Banks' Customers

The findings are also in line with Ajzen (1991) with regards to the facilitating conditions that were found to have a significant positive effect on customers' intention to use E-banking services. These conditions mainly refer to the government encouragement and support of E-banking services, the social environment support of the implementation of E-banking services, as well as the level of country's safety, political stability and security that indirectly favour the use of E-banking services. As such, the government authorities have a major role to play in order to enhance the Islamic banking practice in terms of E-banking services.

Nevertheless, the findings of the current study contradict with the suggestions by Rogers (1983) regarding uncertainty which was found to have no significant effect on the customers' intention to use E-banking services. This might be explained by the fact that the Omani customers perceive the E-banking services offered by Islamic banks as relatively trustworthy/not risky, and reliable. As such, it is not considered a significant factor that influence the customers' decision to use E-banking services or otherwise. However, these findings are in line with the low uncertainty avoidance societies that usually embrace changing circumstances, and have relatively higher tolerance for uncertainty (Hofstede and Bond, 1984).

Finally, the findings showed high tendency of Islamic banks' customers in Oman to use E-banking services. This indicates that the respondents are satisfied with their E-banking experience and intend to continue using these services and their enhanced versions in the future. This is illustrated by their appreciation of the relative advantage and ease of use of e-banking that are prerequisite for regularly using it in their daily transactions, together with the facilitating conditions that should be consistently preserved and maintained by the government authorities.

\section{Conclusion and Recommendation}

\section{Conclusion}

In summary, the main purpose of the current study was to analyse the perception of E-banking services among Islamic banks' customers in Oman and the factors that might influence their decision. Accordingly, linear regression analysis and one sample $t$-test were used to analyse data obtained from 188 Omani Islamic banks' customers. Overall, the findings showed high tendency and willingness of Islamic banks' customers in Oman to adopt E-banking services. Furthermore, the findings revealed that relative advantage, self-efficacy, perceived ease of use and facilitating conditions 
Echchabi, Al-Hajri, \& Tanas | Analysis of E-Banking acceptance in Oman: The Case of Islamic Banks' Customers

have a significant positive impact on E-banking adoption by Islamic banks' customers, while uncertainty had no significant effect on E-banking usage.

It is noteworthy that the model used in this study is a valuable extension of the innovation and technology adoption models. Moreover, the above findings provide empirical support to the model, and provide evidence of its applicability and suitability to similar settings. In addition, these findings provide clear guidelines to the practitioners and policymakers on the core dimensions to be stressed in order to promote the effective adoption of Ebanking services in Oman for Islamic banks' customers, and which is expected to increase the competitiveness of Islamic banking in the dual banking sector of Oman. Particularly, the practitioners should focus on the relative advantage of E-banking services compared to the traditional services, in terms of cost and time saving, efficiency. In addition, the government authorities are required to set up all the required conditions and regulations that contributes to the proper and safe execution and management of the advanced technological banking services. Moreover, it is recommended that Islamic continuously update the customers on the latest technological applications and services that can enhance the performance of their daily banking transactions. These advances in the banking technology have to be as much as possible made easy and handy to the customers.

\section{Recommendations}

Finally, the future studies are recommended to extend the current findings to other settings in order to test and validate the model developed in the current study. Moreover, they are recommended to cover a larger sample that includes the customers of both Islamic and conventional banks and compare between them to identify any differences in adoption patterns.

Similarly, the future studies are recommended to compare between the customers' perception and expectations regarding the E-banking services offered by Islamic banks. This will help the Islamic banks to make the necessary developments to satisfy and retain their customers by providing them better E-banking services. As a result, they would have an opportunity to position themselves in a favourable competitive position with the conventional banks. 
Echchabi, Al-Hajri, \& Tanas | Analysis of E-Banking acceptance in Oman: The Case of Islamic Banks' Customers

\section{References}

Al-Ajman, A.S., \& Md Nor, K. (2013). Customers' Adoption of Internet Banking Service: An Empirical Examination of the Theory of Planned Behavior in Yemen. International Journal of Business and Commerce, 2(5), 44-58.

Al-Shbiel, S.O., \& Ahmad, M.A. (2016). A Theoretical Discussion of Electronic Banking in Jordan by Integrating Technology Acceptance Model and Theory of Planned Behavior. International Journal of Academic Research in Accounting Finance and Management Sciences, 6(3), 272-284.

Ajzen, I., \& Fishbein, M. (1980). Understanding attitudes and predicting social behaviour. Englewood Cliffs: Prentice-Hall.

Ajzen, I. (1991). The Theory of Planned Behavior. Organizational Behavior and Human Decision Processes, 50(2), 179-211.

Alhinai, Y.S., Albadi, A., Alshihi, F., \& Algharbi, K. (2013). Investigating Determinants of E-banking Adoption by Individuals: Comparing the Impact of System Characteristics and User Traits. International Review of Management and Business Research, 2(2), 371-387.

Alkailani, M. (2016). Factors Affecting the Adoption of Internet Banking in Jordan: An Extended TAM Model. Journal of Marketing Development and Competitiveness, 10(1), 39-52.

Bandura A. (1982). Self-Efficacy Mechanism in Human Agency. Journal of American Psychology, 37(2), 122-147.

Bartlet, J.E., Kotrlik, J.W., \& Higgins, C.C. (2001). Organisational research: Determining appropriate sample size. Information Technology Learning and Performance Journal, 19(1), 43-50.

Brown, I., Hope, R., Mugera, P., Newman, P., \& Stander, A. (2004). The Impact of National Environment on the Adoption of Internet Banking: Comparing Singapore and South Africa. Journal of Global Information Management, 12(2), 1-26.

Carter, L., \& Campbell, R. (2011). The Impact of Trust and Relative Advantage on Internet Voting Diffusion. Journal of Theoretical and Applied Electronic Commerce Research, 6(3), 28-42.

Chong, A.Y., Ooi, K., Lin, B., \& Tan, B. (2010). Online banking adoption: an empirical analysis. International Journal of Bank Marketing, 28(4), 267-287.

Daneshgadeh, S., \& Yildirim, S.O. (2014). Empirical investigation of internet banking usage: The case of Turkey. Procedia Technology, 16(1), 322331.

Davis, F.D. (1989). Perceived usefulness, perceived ease of use and user acceptance of information technology. MIS Quarterly, 13(3), 319340.

Davis, F., Bagozzi, R. \& Warshaw, P. (1989). User Acceptance of Computer Technology: A Comparison of Two Theoretical Models. Management Science, 35(8), 982-1003.

Echchabi, A. (2011). Online banking prospects in Morocco: An extension of Technology Acceptance Model. Journal of Internet Banking and Commerce, 16(3), pp.1-13. 
Echchabi, Al-Hajri, \& Tanas | Analysis of E-Banking acceptance in Oman: The Case of Islamic Banks' Customers

Echchabi, A., \& Olaniyi, O.N. (2012). Malaysian consumers' preferences for Islamic banking attributes. International Journal of Social Economics, 39(11), 859-874.

Echchabi, A., \& Aziz, H.A. (2013). An empirical survey on the prospects of Mobile money in Morocco. Studies in Business and Economics, 8(1), 46-54.

Echchabi, A. (2018). E-Banking acceptance in Thailand: An emphasis on Islamic banks' customers. European Journal of Islamic Finance, 9(1), 1-5.

Fawzy, S.F., \& Esawai, N. (2017). Internet banking adoption in Egypt: Extending technology acceptance model. Journal of Business and Retail Management Research, 12(1), 109-118.

Feraro-Banta, L. (2014). Assessment of electronic banking services in Islamic banks: Bahrain's perspective. International Advanced Research Journal in Science Engineering and Technology, 1(3), 162-169.

Gopi, M., \& Ramayah, T. (2007). Applicability of theory of planned behavior in predicting intention to trade online. International Journal of Emerging Markets, 2(4), 348-360.

Harrison, D., Mykytyn, P., \& Riemenschneider, C. (1997). Executive Decisions about Adoption of Information Technology in Small Business: Theory and Empirical Tests. Information Systems Research, 8(2), 171-95.

Hill, R. (1998). What sample size is enough in internet survey research. Interpersonal Computing and Technology: An Electronic Journal for the $21^{\text {st }}$ Century, 6(1), 1-10.

Hofstede, G. (1980). Culture's Consequences: International Differences in Work-Related Values. Beverly Hills, CA: Sage.

Hofstede, G. (1997). Cultures and Organizations: Software of the Mind. London: McGraw-Hill.

Hofstede, G., \& Bond, M.H. (1984). Hofstede's Culture Dimensions: An Independent Validation Using Rokeach's Value Survey. Journal of Cross-Cultural Psychology, 15(4), 417-433.

Jalal, A., Marzooq, J., \& Nabi, H.A. (2011). Evaluating the Impacts of Online Banking Factors on Motivating the Process of E-banking. Journal of Management and Sustainability, 1(1), 32-42.

Khan, A.P., Khan, S., \& Xiang, I.A.R. (2017). Factors Influencing Consumer Intentions to Adopt Online Banking in Malaysia. Business \& Economic Review, 9(2), 101-134.

Khater, A.H.O., Almansour, B.A.A., \& Mahmoud, M.H. (2016). Factors Influencing Customers' Acceptance of Internet Banking Services in Sudan. International Journal of Science and Research, 5(1), 14291433.

Klobas, J., \& Clyde, L. (2000). Adults Learning to Use the Internet: A Longitudinal Study of Attitudes and Other Factors Associated with Intended Internet Use. Library and Information Science Research, 22(1), 5-34.

Lee, M. (2009). Factors Influencing the Adoption of Internet Banking: An Integration of Technological acceptance model and TPB with Perceived Risk and Perceived Benefit. Electronic Commerce Research and Applications, 8(1), 130-141. 
Echchabi, Al-Hajri, \& Tanas | Analysis of E-Banking acceptance in Oman: The Case of Islamic Banks' Customers

Liao, S., Shao, Y., Wang, H., \& Chen, A. (1999). The Adoption of Virtual Banking: An Empirical Study. International journal of Information Management, 19(1), 63-74.

Mathieson, K. (1991). Predicting User Intentions: Comparing the Technology Acceptance Model with the Theory of Planned Behavior. Information Systems Research, 2(3), 173-191.

Mishra, D., Akman, I., \& Mishra, A. (2014). Theory of Reasoned Action application for Green Information Technology acceptance. Computers in Human Behaviour, 36(6), 29-40.

Mukhtar, M. (2015). Perceptions of UK Based Customers toward Internet Banking in the United Kingdom. Journal of Internet Banking and Commerce, 20(1), 1-38.

Nasri, W., \& Charfeddine, L. (2012). An Exploration of Facebook. Com Adoption in Tunisia Using Technology Acceptance Model and Theory of Reasoned Action. Interdisciplinary Journal of Contemporary Research in Business, 4(5), 948-969.

Nulty, D.D. (2008). The adequacy of response rates to online and paper survey: What can be done? Assessment and Evaluation in Higher Education, 33(3), 301-314.

Nunnally, J.C. (1978). Psychometric theory, Second Edition. New York: McGraw-Hill.

Otieno, O.C., Liyala, S., Odongo, B.C., \& Abeka, S. (2016). Theory of Reasoned Action as an Underpinning to Technological Innovation Adoption Studies. World Journal of Computer Application and Technology, 4(1), 1-7.

Rahi, S., Abd. Ghani, M., \& Alnaser, M.I. (2017). Predicting customer's intentions to use internet banking: the role of technology acceptance model (TAM) in e-banking. Management Science Letters, 7(1), 513-524.

Rogers, E.M. (1983). Diffusion of innovations (5th ed.), New York: Free Press.

Sahin, I. (2006). Detailed review of rogers' diffusion of innovations theory and educational technology-related studies based on rogers' theory. The Turkish Online Journal of Educational Technology, 5(2), 14-23.

Sanni, S.A., Ngah, Z.A., Abdul Karim, N.H., Abdullah, N., \& Waheed, M. (2013). Using the Diffusion of Innovation Concept to Explain the Factors That Contribute to the Adoption Rate of E-journal Publishing. Serials Review, $x x(\mathrm{xx}), \mathrm{xx}-\mathrm{xx}$.

Sheppard, B., Hartwick, J., \& Warshaw. (1988). The Theory of Reasoned Action: A Meta-Analysis of Past Research with Recommendations for Modifications and Future Research. Journal of Consumer Research, 15(3), 325-43.

Siraye, Z. (2014). Customers' adoption of electronic banking service channels in Ethiopia: an integration of technology acceptance model and perceived risk with theory of planned behavior. International Journal of Electronic Finance, 8(1), 21-34.

Teo, T., Lee, C.B., \& Chai, C.S. (2008). Understanding pre-service teachers' computer attitudes: Applying and extending the Technology Acceptance Model. Journal of Computer Assisted Learning, 24(2), 128-143. 
Echchabi, Al-Hajri, \& Tanas | Analysis of E-Banking acceptance in Oman: The Case of Islamic Banks' Customers

Warshaw, P., \& Davis, F. (1985). Disentangling Behavior Intention and Behavioral expectation. Journal of experimental social Psychology, 21(3), 213-28.

Yuksel, I. (2015). Rogers' Diffusion of Innovation Model in Action: Individual Innovativeness Profiles of Pre-service Teachers in Turkey. Croatian Journal of Education, 17(2), 507-534.

Zainuddin, N.F.A. (2014). Adoption of E-banking in Islamic banking institutions among Muslim customers in Kedah. Master Thesis, Universiti Utara Malaysia, Malaysia.

Ziefle M., \& Jakobs, E.M. (2010). New challenges in human computer interaction: Strategic directions and interdisciplinary trends. Presented at the 4th International Conference on Competitive Manufacturing Technologies. University of Stellenbosch, South Africa. 